American Journal of

Health, Medicine and Nursing Practice (AJHMN)

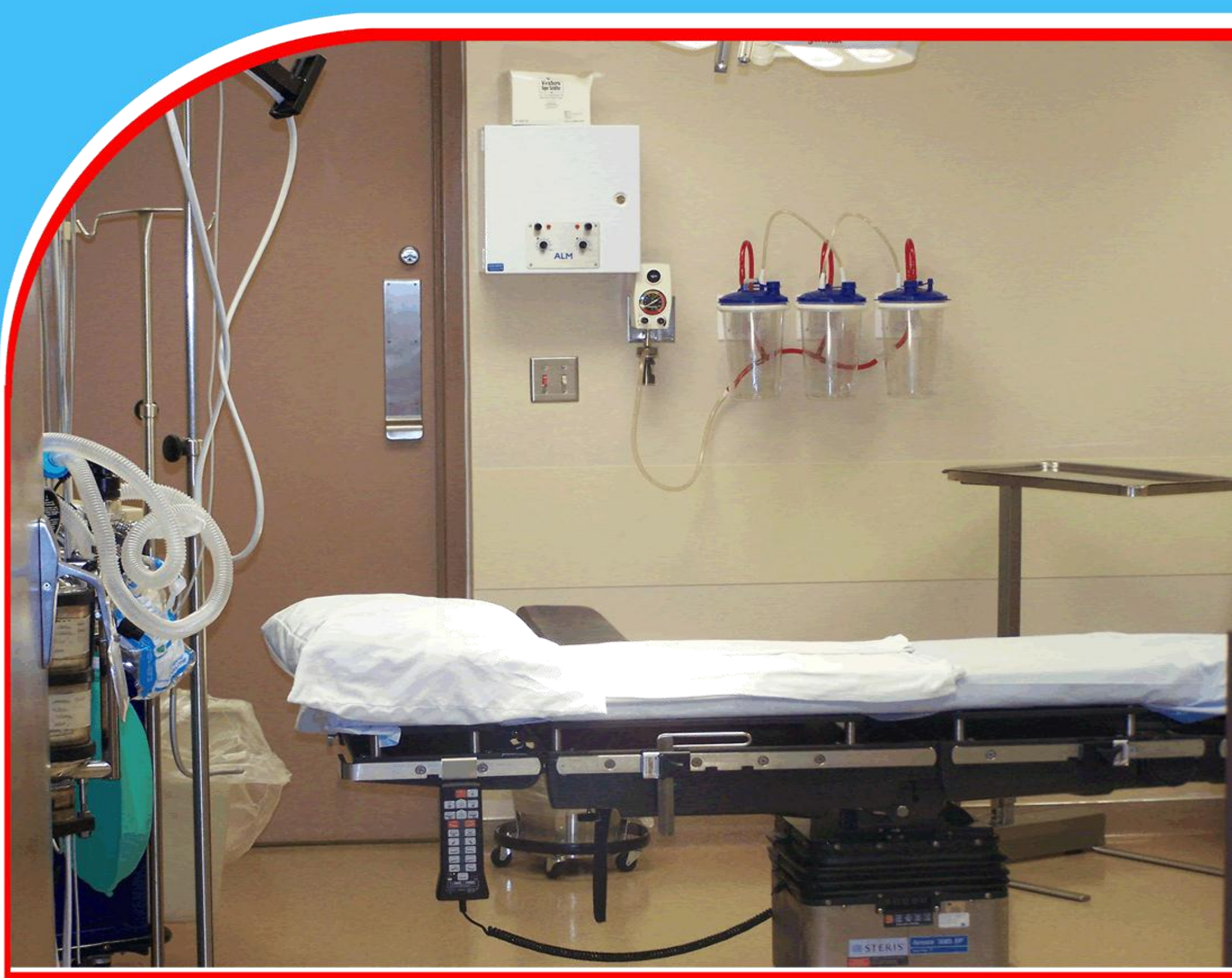

THE COMPARATIVE STUDY TO DETECT RENAL \& URINARY TRACT CALCULI (NEPHROLITHIASIS AND UROLITHIASIS) ON ULTRASOUND AND CT.

Mahnoor Pracha, Amtullah Fatima, Najeebullah Alakozai, Azizullah Alakozai, Taiba Aslam, Rana Muhammad Athar Azeem Shams, Amna Babar, and Hafiz Muhammad Rizwan

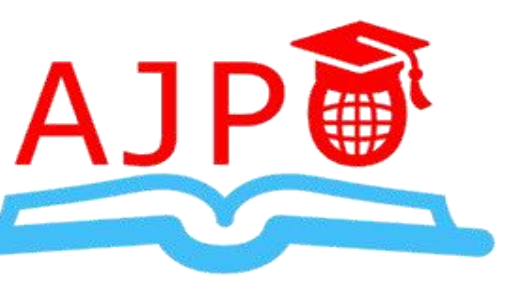




\title{
THE COMPARATIVE STUDY TO DETECT RENAL \& URINARY TRACT CALCULI (NEPHROLITHIASIS AND UROLITHIASIS) ON ULTRASOUND AND CT.
}

\author{
${ }^{1}$ Mahnoor Pracha, ${ }^{2}$ Amtullah Fatima, ${ }^{3}$ Najeebullah Alakozai, ${ }^{4}$ Azizullah Alakozai, \\ ${ }^{5}$ Taiba Aslam, ${ }^{6}$ Rana Muhammad Athar Azeem Shams, ${ }^{7}$ Amna Babar, and ${ }^{8}$ Hafiz \\ Muhammad Rizwan \\ 1,2,3,4,Doctor of Medical Imaging Technology, Department of Allied Health Sciences, \\ Superior College Lahore, University Campus, Pakistan. \\ ${ }^{5} \mathrm{MID}$, Lecturer, Department of Allied Health Sciences, Superior College Lahore, University \\ Campus, Pakistan. \\ ${ }^{6,8}$ Masters in Medical Imaging Technology, Lecturer, Department of Allied Health \\ Sciences, Superior College Lahore, University Campus, Pakistan. \\ ${ }^{7}$ Masters in Diagnostic Ultrasound, Lecturer, Department of Allied Health Sciences, \\ Superior College Lahore, University Campus, Pakistan. \\ Corresponding Author's Email:mahnoorpracha418@gmail.com
}

\begin{abstract}
Background: Ultrasound is a non-invasive imaging modality, and it is cost effective while CT in invasive that uses ionizing radiations, yet it is difficult on ultrasound to diagnose calculi in ureter hence for evaluation of ureteric calculi CT scan is gold standard modality.

Objective: To compare the detection of renal\& urinary tract calculi (nephrolithiasis \& urolithiasis) on ultrasound and CT.

Material and methods: The data bases PubMed, ProQuest, and Google scholar and research gate were searched with the key words: nephrolithiasis on ultrasound and CT, sensitivity, specificity, from 2010 to 2021. For inclusion and exclusion of studies independently screened the titles and abstracts of full and related articles. Articles that had information about nephrolithiasis, urolithiasis at ultrasound and CT and its sensitivity and specificity were included.

Results: In total, 28 studies were found on renal \& urinary tract calculi at ultrasound and computed tomography. This literature review demonstrates that computed tomography is characterized by high sensitivity and specificity in diagnosing renal, ureteric calculi while ultrasound has low sensitivity and specificity.

Conclusions: Ultrasound is the best modality for imaging calculi within the kidney, a well hyper echoic mass with posterior acoustic shadow is identified as stone on gray scale, color Doppler can be used for demarcation of stone. At Color Doppler twinkling artifact appears around the calculi hence it can be differentiated by hyper echoic renal sinuses but this is crucially dependant on the size and anatomical position of the stone. The ultrasonic evaluation either overestimates or misinterprets the calculi size while CT gives an exact measurement, position with authentic sensitivity and specificity. Hence, CT is the gold standard for detection of renal calculi.

Recommendation: Ultrasound is a non-invasive imaging modality and it is cost effective while CT in invasive that uses ionizing radiations, yet it is difficult on ultrasound to diagnose calculi in ureter hence for evaluation of ureteric calculi CT scan is gold standard modality.
\end{abstract}

Keywords: CT, Nephrolithiasis, urolithiasis, renal calculi, ultrasound, sensitivity, specificity. 


\section{INTRODUCTION}

Nephrolithiasis, also known as kidney stone disease, is the development of renal calculi caused by an imbalance in the solubility and precipitation of salts in the kidneys. The Males above the age of 50 had the greatest frequency of Nephrolithiasis. Males aged 40-60 years old accounted for 17.8 percent of those aged less than 61 years. Patient presents with pain in lumber region, hematuria, burning sensation during urination. Hypertension, obesity, and type 2 diabetes are secondary of symptoms of nephrolithiasis ${ }^{1}$. In India, the lifetime incidence of renal calculi its $7 \%$ among females and $12 \%$ among males ${ }^{2}$. The $\mathrm{pH}$ and temperature influence the transition from liquid to solid phase. The precise concentrations of additional ingredients the amount of urinary. Saturation in terms of stone-forming components like as phosphate, calcium, oxalate, uric acid, cysteine, and a low level of the amount of urine is a possible factor for crystallization ${ }^{2}$. The Ultrasound is deemed lesser to Computed Tomography in terms of determining size of the calculus. Changes in gain and depth, as well as other modes such as angling and S (stone-specific) mode, are key variables increasing accuracy ${ }^{3}$.

The Ultrasound overestimated stone size as depth increased, as did gain at a given depth. As a result, proper adjustment of depth and gain enhances the accuracy of stone size estimate ${ }^{4}$. Harmonic imaging is use to increase the accuracy of stone measuring. A novel mode in the ultrasound known as mode of stone-specific, which aids in accurately distinguishing between the stone and the surrounding buildings. When compared to the standard B mode, the S mode US improves sensitivity. The sensitivity for S mode was 78 percent vs. 61 percent for standard US ${ }^{5}$. Acoustic shadow width investigated and proved to increase stone measuring accuracy. Measuring the width on ultrasound of the shadow is accurate and this approach increases the accuracy with $\mathrm{ct}^{6}$. The twinkling artifact appears is a quick alternating signal of color Doppler which mimics turbulent flow and is frequently detected when a stationary with irregular surface that is reflecting, in case of renal stone. In Doppler, it appears as jumbled pattern. A spectrum of twinkling shows aliasing ${ }^{7}$.

NCCT is officially the method for diagnosing stones. NCCT has certain benefits over usg which is unaffected by intestinal gas. It is predicted that 1 in 1400 people over the age of 60 who receive NCCT may develops a cancer or leukemia. The primary advantages of US over CT are its lower cost, lack of radiation, and mobility. These radiations have cumulative effects, and cumulative exposure increases the risk of future cancers. The impact builds up over time, therefore young individuals and pregnant women should avoid being exposed to radiation ${ }^{8}$. It is effective in detecting renal, vuj, and calculi, but it is ineffective at diagnosing ureteral stones, particularly those in the mid ureteral region. It is also insensitive to tiny calculi smaller than $2 \mathrm{~mm}$ in size ${ }^{9}$.

The urinary system is responsible for excreting waste products of metabolism and foreign substances from the body, as well as maintaining a proper water balance and electrolyte balance in the blood and tissue fluids such as sodium, potassium, calcium, and so on. The urinary system is made up of the following components: kidneys function as excretory organs, ureters as the ducts, urinary bladder serves as a urinary reservoir. Urethra is channeled to the outside. The kidneys are a pair of organs that are around $11 \mathrm{~cm}(4.25 \mathrm{inch})$ in length, $6 \mathrm{~cm}(\mathrm{~s} 2.5 \mathrm{inch})$ in breadth, and $3 \mathrm{~cm}$ (1.25 inch) in thickness. They are arranged obliquely rather than vertically, with their upper poles closer to the midline than their lower poles, behind the peritoneum of the posterior abdominal wall $^{10}$. A ureter is a channel that transports urine from the kidney to the bladder. Bladder urinary: 
The bladder serves as a reservoir for urine collected from the kidneys via the ureter. It is a muscle sac lined by mucous membrane and coated with transitional epithelium. The bladder must be evaluated in both its empty and full stages. A calculus is a precipitated substance produced from a secretion and deposited in an excretory duct. The mode of calculus creation is enigmatic ${ }^{11}$.

\section{MATERIAL AND METHOD}

\section{Search Strategy}

The data bases PubMed, ProQuest, Google scholar, and research gate were searched with the key words: renal stones, ureteric calculi, nephrolithiasis, sensitivity, specificity, accuracy and CT, ultrasound from 2010 to 2021 . Only those studies were enrolled in the review which includes the renal calculi.

\section{Selection Criteria}

For inclusion and exclusion of studies independently screened the titles and abstracts of full-length related articles. The disparity of the reviewer was fixed by consensus. Studies having information of role of ultrasound in diagnosis of nephrolithiasis was included. The qualitative data was extracted from the articles, journals and thesis.

\section{Study Characteristics}

Total 54 studies were found after searching data bases and 23 of them were excluded due to duplication, 3 studies were excluded due to irrelevant or insufficient data and rest of studies rejected based on title and abstract. Flow chart summarizes the reviewed flow records in Figure 1. Only original research articles were included in this research including the systematic reviews and meta-analysis reviews.

\section{Data Synthesis and analysis Procedure}

The eligible studies were first categorized according to renal calculi and calculate overall mean of sensitivity, specificity. All mean sensitivity, specificity and accuracy were calculated according to modality chosen by the researcher for the accurately visualization of calculi either ultrasound or CT.

\section{RESULTS AND DISCUSSION}

A study by Sharad et al., (2020) showed that CTU was rather extremely sensitive and specific for ureteric calculi. Sensitivity, specificity, accuracy, positive predictive value and negative predictive value of USG were calculated with CTU as the gold standard. The renal stone sensitivity and specificity on USG was $53 \%$ and on CTU it was $85 \%$ respectively. The finding of ultrasound about ureteric calculus was sensitivity and specificity was $12 \%$ and on CTU it was $97 \%$ respectively. The detection of calculi in urinary bladder sensitivity and specificity on ultrasound was $20 \%$ and on CTU, it was $100 \%$ respectively. This shows that USG is far less accurate in diagnosing ureteric and bladder stones ${ }^{1}$.

A study by Nadya et al., (2019) used $92 \%$ of patients' access sheath. The results showed that $73 \%$ were stone free when assessed on CT, the residual fragments among $2 \%$ of patients were in $1 \mathrm{~mm}$, $16 \%$ were in $2-4 \mathrm{~mm}$ and $9 \%$ were in $>4 \mathrm{~mm}$ of kidneys. It was concluded that according to precise CT evaluation, the accurate stone-free proportion in people with urs for renal calculi with of stones was $73 \%^{2}$. Mohankumar et al., (2018) conducted study which aimed to use standard 
method for diagnosing stone disease in a patient. They concluded that it is an appropriate modality because of its less cost, lack of rays, and ease of accessibility. The sole drawback is that it has lower sensitivity and specificity when compared to $\mathrm{CT}^{12}$. Matthew et al., (2020) conducted a study whose objective was to compare the precision of ultra-low-dose computed tomography (ULDCT) with standard-dose computed tomography (SDCT) in the assessment of patients with clinically significant cancer. Calculi that are clinically important $(3 \mathrm{~mm})$ ULDCT identified them with excellent specificity (97.6 percent) and sensitivity (100\%) in comparison to total detection (specificity) 91.2 percent, with a sensitivity of 58.8 percent). ULDCT and SDCT were both extremely effective ${ }^{13}$.

To access prognostic value of kidney ultrasound for urolithiasis in children, Nathaneil et al., (2018) observed that, in clinical practice, the Ultrasound has a high specificity for identifying nephrolithiasis in children, but only a moderate sensitivity, with many false negatives ${ }^{14}$. The US exaggerated stone size, which was particularly evident with smaller calculi in a study conducted by Andrew et al., (2010). The study found out that stones of $5 \mathrm{~mm}$ in size, US measures were $1.9 \mathrm{~mm}, 1.2 \mathrm{~mm}$ larger than CT (P.001). For $60 \%$ of stones with a diameter of $5 \mathrm{~mm}$, US and CT measures were incompatible ${ }^{15}$. In a research by James et al., (2012), the precise role of ultrasound in detecting suspected urolithiasis was discussed and ultrasound sensitivity, specificity, and negative predictive value for calculi seen were compared on $\mathrm{CT}$ and the overestimation of it was also explained ${ }^{16}$.

\section{CONCLUSION}

Ultrasound is the best modality for imaging calculi within the kidney, a well hyper echoic mass with posterior acoustic shadow is identified as stone on gray scale, color Doppler can be used for demarcation of stone. At Color Doppler twinkling artifact appears around the calculi hence it can be differentiated by hyper echoic renal sinuses but this is crucially dependant on the size and anatomical position of the stone. The ultrasonic evaluation either overestimates or misinterprets the calculi size while CT gives an exact measurement, position with authentic sensitivity and specificity. Hence, CT is the gold standard for detection of renal calculi.

\section{RECOMMENDATION}

Ultrasound is a non-invasive imaging modality and it is cost effective while CT in invasive that uses ionizing radiations, yet it is difficult on ultrasound to diagnose calculi in ureter hence for evaluation of ureteric calculi CT scan is gold standard modality. 
American Journal of Health, Medicine and Nursing Practice

ISSN 2520-4017 (Online)

Vol.6, Issue 5, pp 25 - 37, 2021

PRISMA Flow Diagram 1
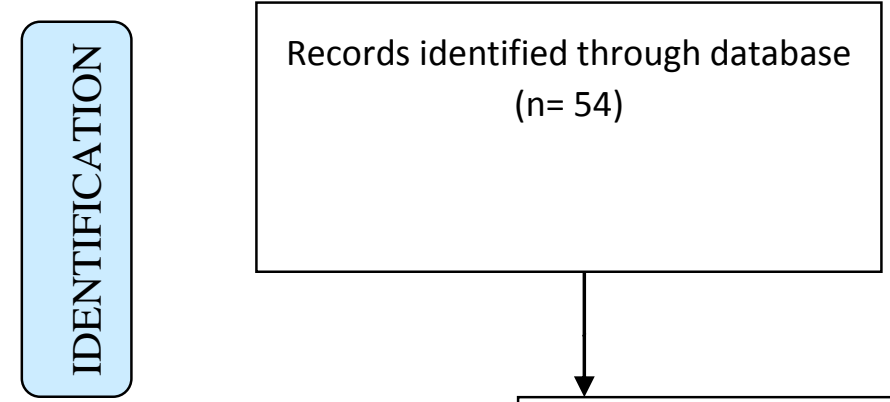

Additional records identified

through other sources

$$
(n=54)
$$

Records after duplicates removed

$$
(\mathrm{n}=23)
$$
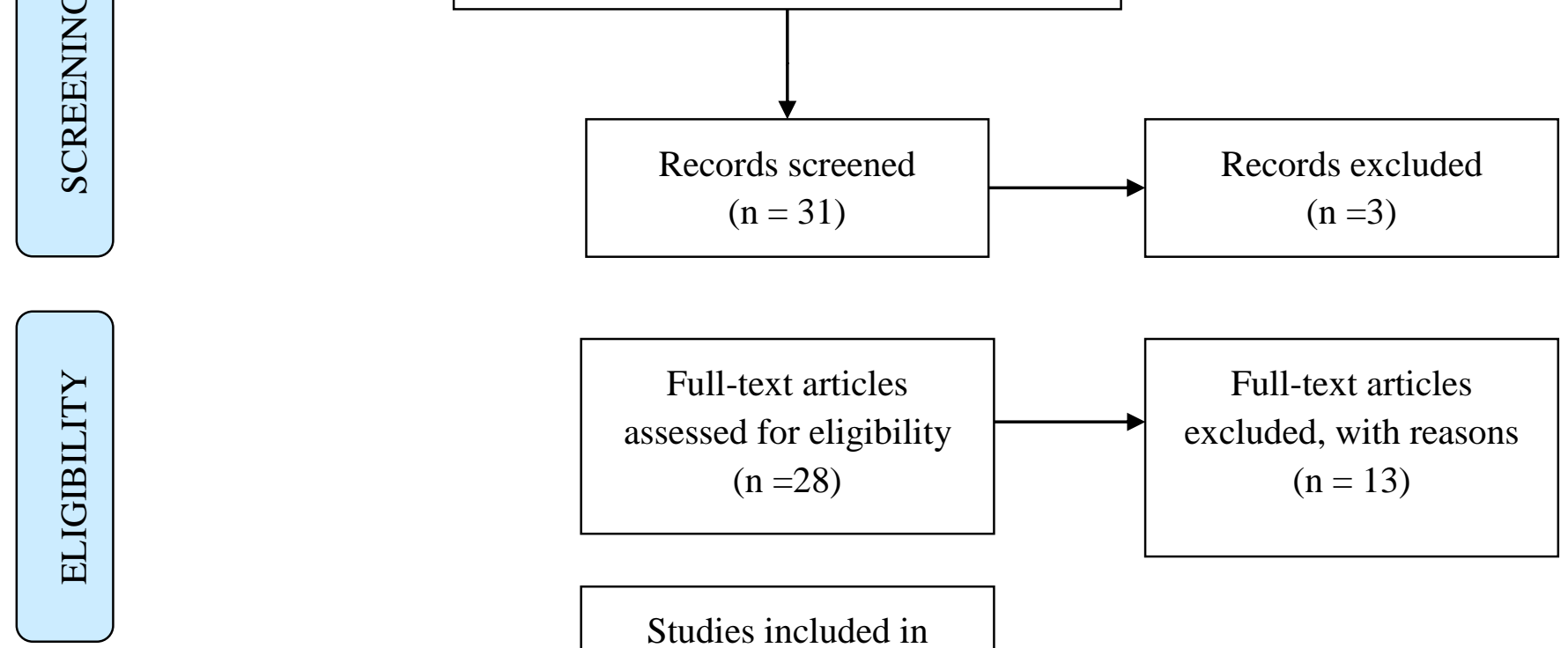

Studies included in qualitative synthesis

$$
(\mathrm{n}=15)
$$

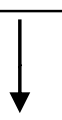

Studies included in quantitative synthesis (meta-analysis)

$$
(\mathrm{n}=15)
$$




\begin{tabular}{|c|c|c|c|c|c|c|c|c|}
\hline $\begin{array}{l}\mathrm{Sr} \\
. \#\end{array}$ & $\begin{array}{l}\text { Author \& } \\
\text { Year }\end{array}$ & Journal & $\begin{array}{l}\text { Sample } \\
\text { size }\end{array}$ & $\begin{array}{l}\text { Sensi- } \\
\text { tivity } \\
\text { CT }\end{array}$ & $\begin{array}{l}\text { Specifi- } \\
\text { city on } \\
\text { CT }(\%)\end{array}$ & $\begin{array}{l}\text { Sensitivity } \\
\text { on ultra- } \\
\text { sound (\%) }\end{array}$ & $\begin{array}{l}\text { Specificity } \\
\text { on ultra- } \\
\text { sound (\%) }\end{array}$ & Conclusion \\
\hline 1. & $\begin{array}{l}\text { Sharad } \\
\text { Konedekar } \\
\text { et al., } 2020\end{array}$ & Radiology & 150 & 85 & - & 53 & - & $\begin{array}{l}\text { Precision of ultrasound in } \\
\text { diagnosis renal, ureteric and } \\
\text { urinary bladder calculi were } \\
68,80 \text { and } 99 \text { percent } \\
\text { respectively }\end{array}$ \\
\hline 2. & $\begin{array}{c}\text { Nadya E et } \\
\text { al } 2019\end{array}$ & Urology & 221 & 92 & 73 & - & - & $\begin{array}{l}\text { According to precise CT } \\
\text { evaluation, the accurate } \\
\text { stone-free proportion in } \\
\text { people getting flexible URS } \\
\text { for renal calculi with active } \\
\text { basketing of stones was } 73 \% \text {. } \\
\text { The majority of remaining } \\
\text { pieces in patients with renal } \\
\text { calculi are } 2-4 \text { mm in size, } \\
\text { making URS a therapeutic } \\
\text { option for renal stones with } \\
\text { superior stone-free outcomes }\end{array}$ \\
\hline 3. & $\begin{array}{l}\text { Nathaneil } \\
\text { et al., } 2018\end{array}$ & $\begin{array}{l}\text { Pediatric } \\
\text { radiology }\end{array}$ & 69 & 59 & 72 & 67 & 97 & $\begin{array}{l}\text { Ultrasound has a high } \\
\text { specificity for identifying } \\
\text { nephrolithiasis in children, } \\
\text { but only a moderate } \\
\text { sensitivity, with many false } \\
\text { negatives }\end{array}$ \\
\hline 4. & $\begin{array}{c}\text { Mohankum } \\
\text { ar et al., } \\
2019\end{array}$ & $\begin{array}{l}\text { Research } \\
\text { and reports } \\
\text { in urology }\end{array}$ & 100 & - & - & 45 & 88 & $\begin{array}{l}\text { An appropriate first-line } \\
\text { imaging modality for } \\
\text { nephrolithiasis because of its } \\
\text { low cost, lack of radiation, } \\
\text { and ease of availability. The } \\
\text { sole drawback is that it has }\end{array}$ \\
\hline
\end{tabular}


American Journal of Health, Medicine and Nursing Practice

ISSN 2520-4017 (Online)

Vol.6, Issue 5, pp $25-37,2021$

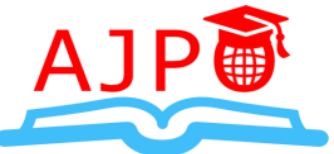

www.ajpojournals.org

\begin{tabular}{|c|c|c|c|c|c|c|c|c|}
\hline & & & & & & & & $\begin{array}{l}\text { lower sensitivity and } \\
\text { specificity when compared to } \\
\text { CT. The inclusion of newer } \\
\text { models can enhance stone } \\
\text { size measuring accuracy }\end{array}$ \\
\hline 5. & $\begin{array}{l}\text { Turo Kano } \\
\text { et al., } 2014\end{array}$ & Urology & 428 & 70 & 94 & 78 & 83 & $\begin{array}{l}\text { For identifying renal stones, } \\
\text { US was an useful imaging } \\
\text { technique }\end{array}$ \\
\hline 6. & $\begin{array}{l}\text { Letafai et } \\
\text { al., } 2019\end{array}$ & $\begin{array}{c}\text { Doctoral } \\
\text { dissertation } \\
,\end{array}$ & 110 & - & - & 76 & 100 & $\begin{array}{l}\text { Color Doppler twinkling } \\
\text { artifact's sensitivity, } \\
\text { specificity, positive and } \\
\text { negative predictive value, and } \\
\text { accuracy were } 76.8 \text { percent, } \\
100 \text { percent, } 100 \text { percent, } \\
32.4 \text { percent, and } 79 \text { percent, } \\
\text { respectively. Furthermore, } \\
\text { the diagnostic usefulness of } \\
\text { Color Doppler twinkling } \\
\text { artifact was significant in the } \\
\text { identification of renal stones } \\
\text { depending on age, gender, } \\
\text { posterior shadow, renal } \\
\text { involvement, and stone } \\
\text { placement in the kidney }\end{array}$ \\
\hline 7. & $\begin{array}{l}\text { Kevan et } \\
\text { al., } 2016\end{array}$ & Urology & 155 & 51 & 51 & 84 & 84 & $\begin{array}{l}\text { The US substantially } \\
\text { overestimated stone size, } \\
\text { which was especially } \\
\text { noticeable for tiny }(5 \mathrm{~mm}) \\
\text { stones. When weighing } \\
\text { endourologic treatment } \\
\text { choices, consider the } \\
\text { possibility of systematic } \\
\text { overestimation of stone size }\end{array}$ \\
\hline
\end{tabular}


American Journal of Health, Medicine and Nursing Practice

ISSN 2520-4017 (Online)

Vol.6, Issue 5, pp 25 - 37, 2021

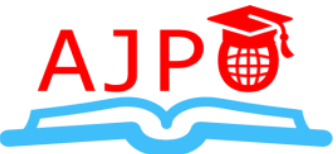

www.ajpojournals.org

\begin{tabular}{|c|c|c|c|c|c|c|c|c|}
\hline & & & & & & & & $\begin{array}{l}\text { using conventional US } \\
\text { methods }\end{array}$ \\
\hline 8. & $\begin{array}{l}\text { Andrew ray } \\
\text { et al., } 2010\end{array}$ & Urology & 60 & - & - & 45 & 88 & $\begin{array}{l}\text { US overestimates renal } \\
\text { calculi in urolithiasis, a } \\
\text { finding that may have } \\
\text { implications for calculi } \\
\text { management. Discordance in } \\
\text { stone measurement varies } \\
\text { with size and is greatest in } \\
\text { calculi } \leq 5 \mathrm{~mm} \text {. US } \\
\text { measurement of skin-stone- } \\
\text { distance is an important } \\
\text { determinant of error in } \\
\text { Sonographic measurement of } \\
\text { renal stone. }\end{array}$ \\
\hline 9. & $\begin{array}{l}\text { Vishnu } \\
\text { ganeson et } \\
\text { al., } 2017\end{array}$ & BJUI & 552 & - & - & 54 & 91 & $\begin{array}{l}\text { Using US to guide clinical } \\
\text { decision-making for residual } \\
\text { or asymptomatic calculi is } \\
\text { limited by low sensitivity and } \\
\text { inability to size the stone } \\
\text { accurately. }\end{array}$ \\
\hline 10. & $\begin{array}{c}\text { Rodger F et } \\
\text { al., } 2018\end{array}$ & $\begin{array}{c}\text { Urologia } \\
\text { internation } \\
\text { al }\end{array}$ & 1529 & $72-99$ & $86-100$ & - & - & $\begin{array}{l}\text { LD and ULD CT KUB } \\
\text { provide effective methods of } \\
\text { identifying urinary tract } \\
\text { stones. High diagnostic } \\
\text { accuracy, sensitivity, and } \\
\text { specificity are maintained } \\
\text { despite significant radiation } \\
\text { dose reduction in comparison } \\
\text { to standard dose CT. }\end{array}$ \\
\hline 11. & $\begin{array}{c}\text { James H et } \\
\text { al., } 2012\end{array}$ & $\begin{array}{l}\text { American } \\
\text { journal of }\end{array}$ & 107 & 76.5 & $59.4-88$ & 30.8 & $22.5-40.6$ & $\begin{array}{l}\text { Bedside renal ultrasound had } \\
\text { only a limited impact on the } \\
\text { physicians' clinical } \\
\text { impression of patients with }\end{array}$ \\
\hline
\end{tabular}




\begin{tabular}{|c|c|c|c|c|c|c|c|c|}
\hline & & $\begin{array}{l}\text { emergency } \\
\text { medicine }\end{array}$ & & & & & & $\begin{array}{l}\text { possible ureterolithiasis. The } \\
\text { sensitivity of } \\
\text { sonographic hydronephrosis } \\
\text { was modest for detecting any } \\
\text { ureteral stone, but much } \\
\text { better for detecting a large } \\
\text { stone. Further study is needed } \\
\text { to define the precise role } \\
\text { ultrasound should play in } \\
\text { evaluating patients with } \\
\text { suspected ureterolithiasis. }\end{array}$ \\
\hline 12. & $\begin{array}{c}\text { Kathaleen } \\
\text { putaman et } \\
\text { al., } 2021\end{array}$ & Elsevier & 599 & - & - & 83 & 74 & $\begin{array}{l}\text { Compared to the adult } \\
\text { literature, TA in children has } \\
\text { lower sensitivity, specificity } \\
\text { and positive predictive value, } \\
\text { but similar negative } \\
\text { predictive value for } \\
\text { diagnosing nephrolithiasis. } \\
\text { This may be related to renal } \\
\text { location and smaller stone } \\
\text { size. The presence of TA } \\
\text { should be weighed in the } \\
\text { setting of other clinical and } \\
\text { radiographic evidence of } \\
\text { nephrolithiasis. }\end{array}$ \\
\hline 13. & $\begin{array}{c}\text { Laher et al., } \\
2020\end{array}$ & $\begin{array}{c}\text { European } \\
\text { journal of } \\
\text { medicine }\end{array}$ & 4389 & - & - & 88.1 & 79.22 & $\begin{array}{l}\text { Despite the suboptimal } \\
\text { pooled sensitivity and } \\
\text { specificity of the TA sign and } \\
\text { the large heterogeneity } \\
\text { between published studies, } \\
\text { the current body of evidence } \\
\text { suggests that the colour } \\
\text { Doppler ultrasonographic TA } \\
\text { sign may be useful as a } \\
\text { complementary tool in the }\end{array}$ \\
\hline
\end{tabular}


American Journal of Health, Medicine and Nursing Practice ISSN 2520-4017 (Online)

Vol.6, Issue 5, pp 25 - 37, 2021

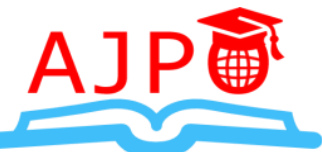

www.ajpojournals.org

\begin{tabular}{|c|c|c|c|c|c|c|c|c|}
\hline & & & & & & & & $\begin{array}{l}\text { diagnostic workup of patients } \\
\text { with suspected urolithiasis. }\end{array}$ \\
\hline 14. & $\begin{array}{l}\text { Trevor A et } \\
\text { al., } 2020\end{array}$ & $\begin{array}{l}\text { European } \\
\text { radiology }\end{array}$ & 1005 & 82 & 97 & - & - & $\begin{array}{l}\text { DECT is an accurate } \\
\text { replacement test for diagnosis } \\
\text { of uric acid calculi in vivo, } \\
\text { such that stone analysis could } \\
\text { be replaced in the diagnostic } \\
\text { pathway. This would enable } \\
\text { earlier initiation of urine } \\
\text { alkalinization. }\end{array}$ \\
\hline 15. & $\begin{array}{l}\text { Mathew et } \\
\text { al., } 2020\end{array}$ & $\begin{array}{c}\text { BJUI } \\
\text { Internation } \\
\text { al }\end{array}$ & 21 & 91 & 58 & - & - & $\begin{array}{l}\text { ULDCT performed similarly } \\
\text { to SDCT for calculus } \\
\text { detection and size estimation } \\
\text { with reduced radiation } \\
\text { exposure. Based on this and } \\
\text { other studies, ULDCT should } \\
\text { be considered as the first-line } \\
\text { modality for evaluation of } \\
\text { renal colic in routine practice. }\end{array}$ \\
\hline
\end{tabular}

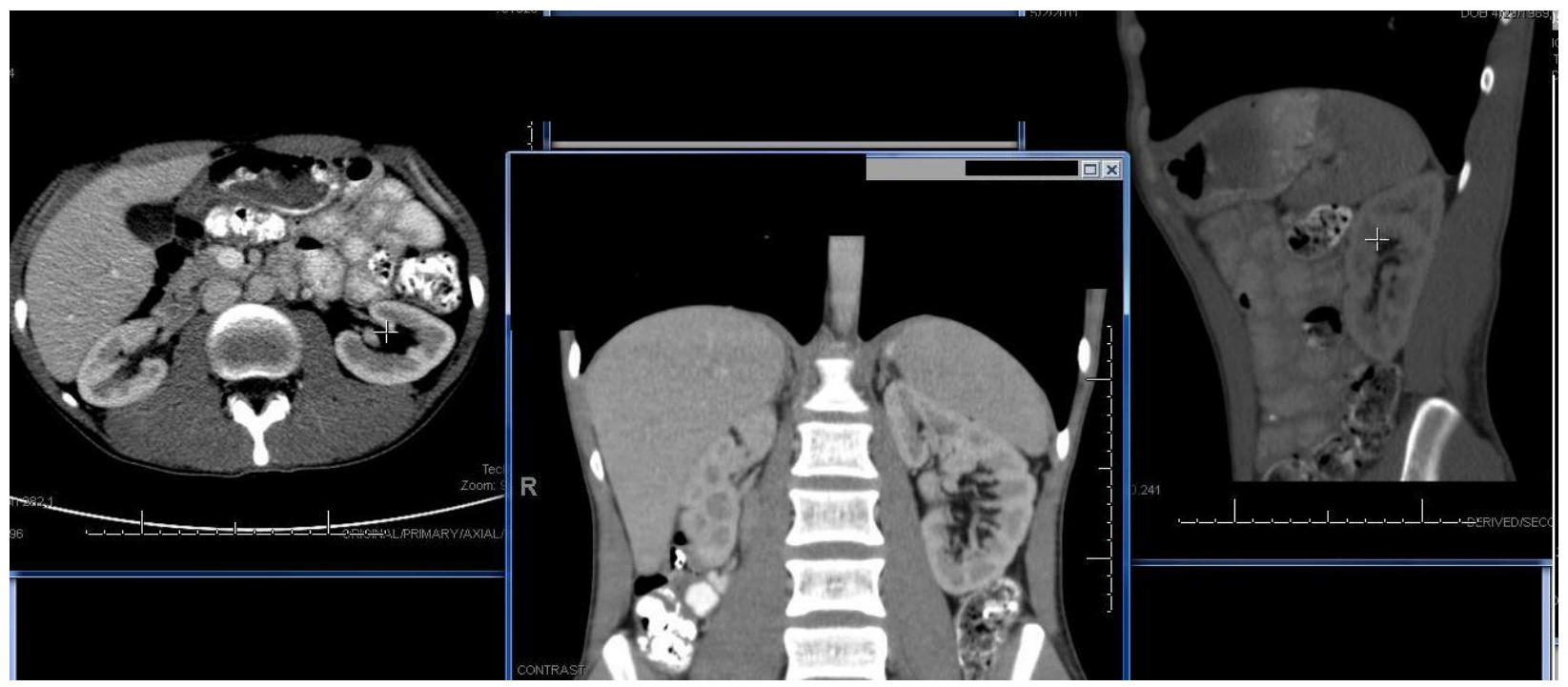

Figure 1: Normal axial, coronal and sagittal cross-sectional anatomy of none enhanced CT. 
American Journal of Health, Medicine and Nursing Practice

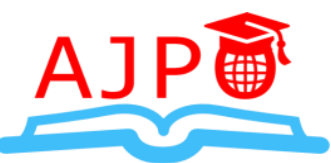
ISSN 2520-4017 (Online)

Vol.6, Issue 5, pp 25 - 37, 2021

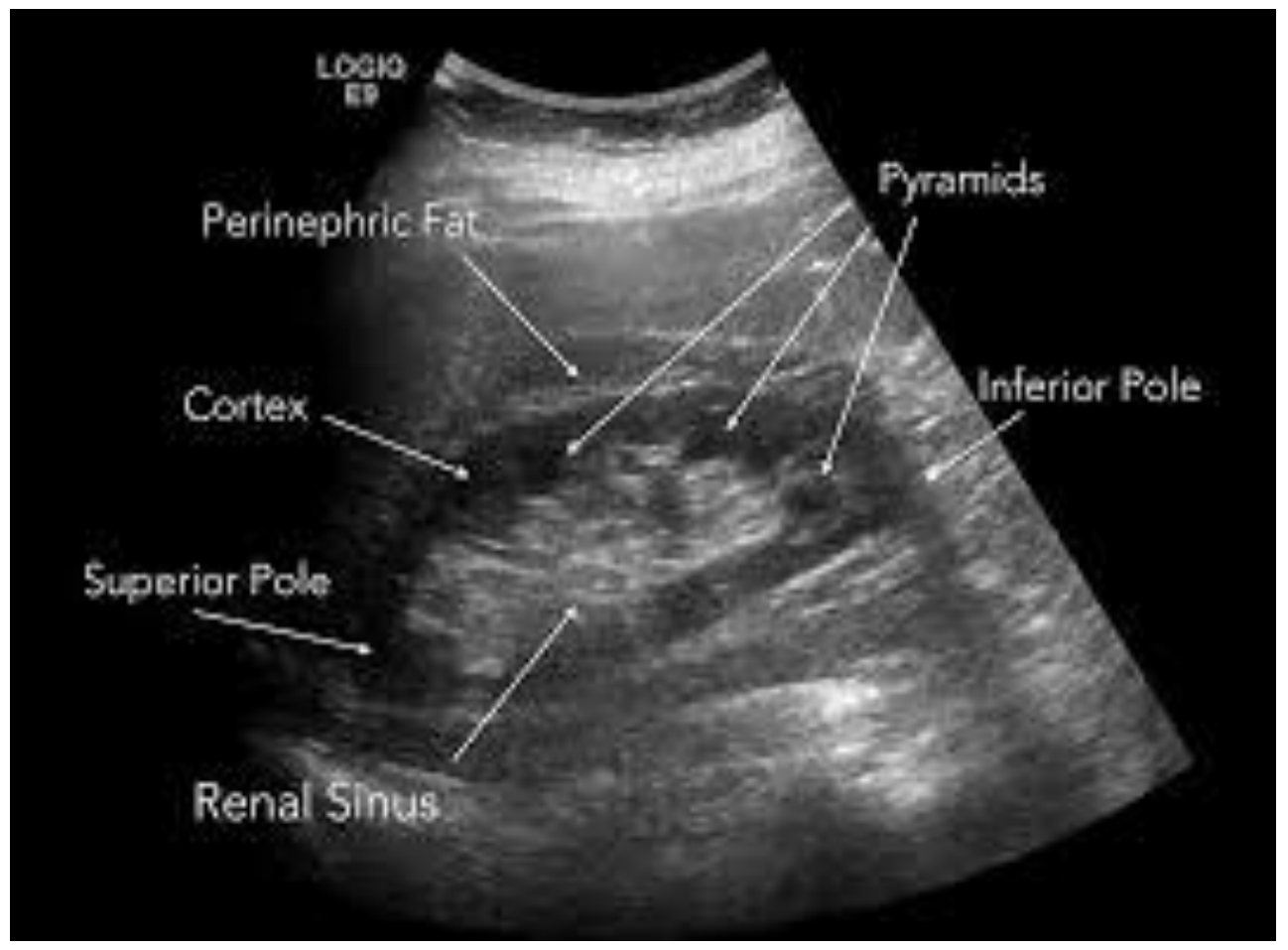

Figure 2: Normal ultrasound gray scale image of kidney.

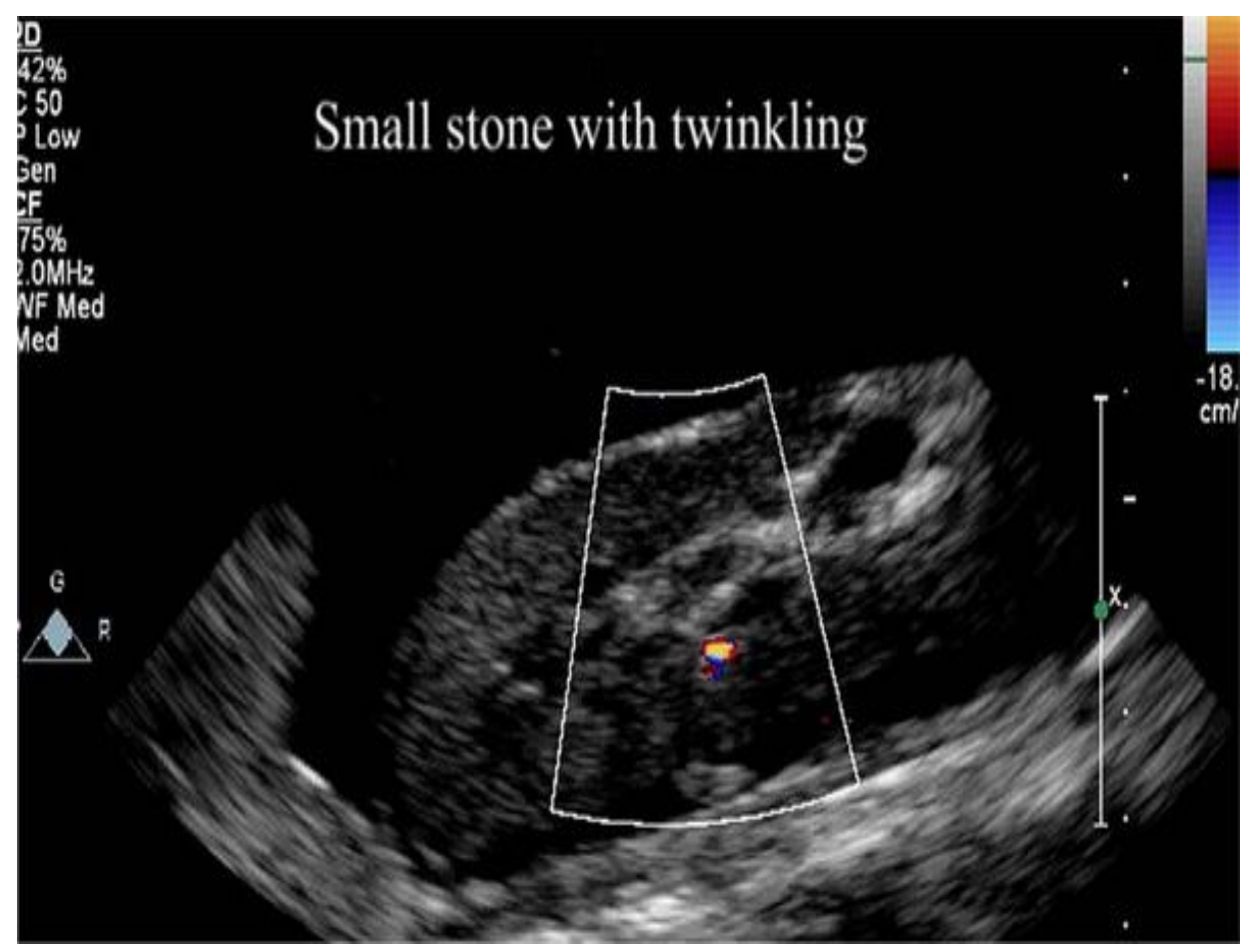

Figure 3: Twinkling artifact on ultrasound 


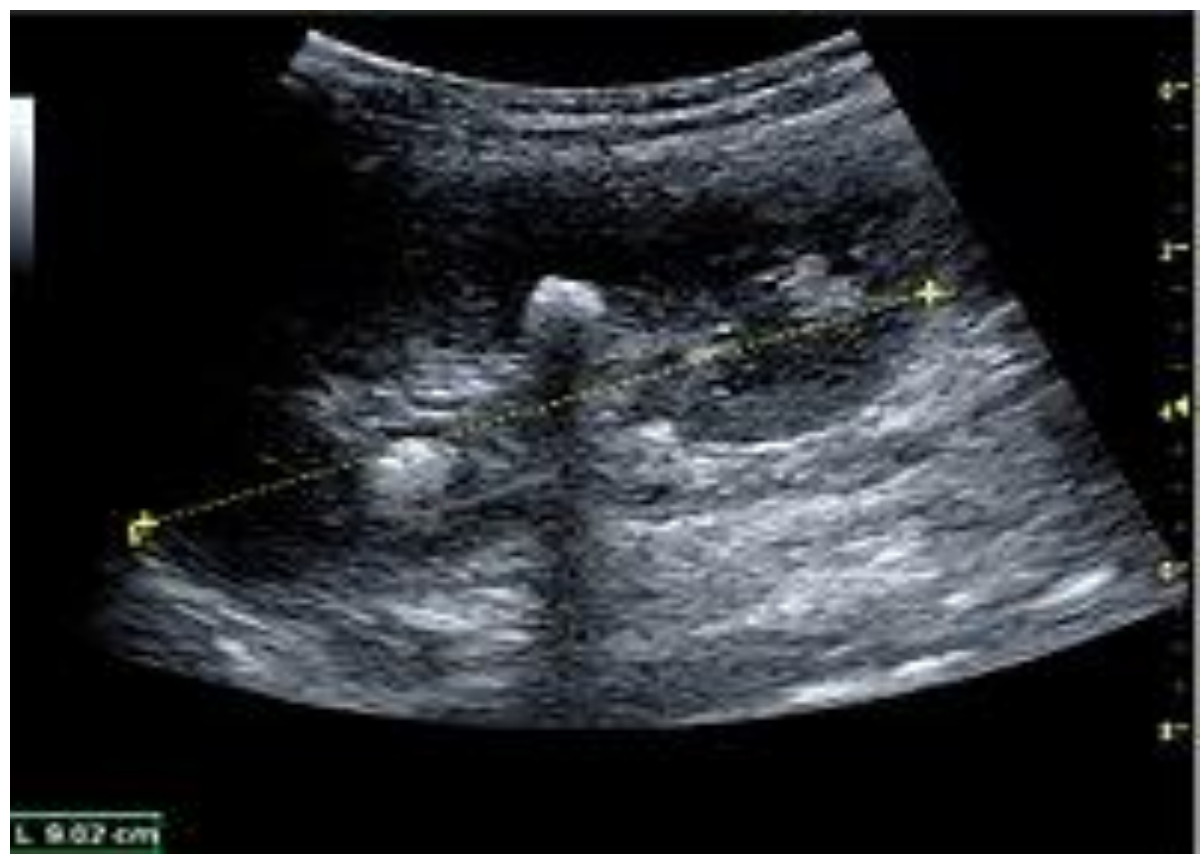

Figure 4: Ultrasound gray scale image showing a mid-pole renal calculus.

\section{References:}

1. Kondekar S, Minne I. Comparative Study of Ultrasound and Computerized Tomography for Nephrolithiasis Detection. Radiology. 2020;5(2):B4-7.

2. York NE, Zheng M, Elmansy HM, Rivera ME, Krambeck AE, Lingeman JE. Stone-free outcomes of flexible ureteroscopy for renal calculi utilizing computed tomography imaging. Urology. 2019 Feb 1;124:52-6.

3. Dunmire B, Lee FC, Hsi RS, Cunitz BW, Paun M, Bailey MR, Sorensen MD, Harper JD. Tools to improve the accuracy of kidney stone sizing with ultrasound. Journal of endourology. 2015 Feb 1;29(2):147-52.

4. Cunitz B, Dunmire B, Paun M, Sapozhnikov O, Kucewicz J, Hsi R, Lee F, Sorensen M, Harper J, Bailey M. Improved detection of kidney stones using an optimized Doppler imaging sequence. In2014 IEEE International Ultrasonics Symposium 2014 Sep 3 (pp. 452-455). IEEE.

5. Dunmire B, Harper JD, Cunitz BW, Lee FC, Hsi R, Liu Z, Bailey MR, Sorensen MD. Use of the acoustic shadow width to determine kidney stone size with ultrasound. The Journal of urology. 2016 Jan;195(1):171-7.

6. Letafati M. Diagnostic value of color Doppler twinkle artifact in renal stones (Doctoral dissertation, Tabriz University of Medical Sciences, Faculty of Medicine)

7. Sternberg KM, Eisner B, Larson T, Hernandez N, Han J, Pais VM. Ultrasonography significantly overestimates stone size when compared to low-dose, noncontrast computed tomography. Urology. 2016 Sep 1;95:67-71.

8. Rahman El Bakry RA. Prospective comparative study between un-enhanced multidetector computed tomography and ultrasonography in evaluation of acute renal colic. Alexandria Journal of Medicine. 2017 Dec 1;53(4):367-71. 
9. Abdalgader SB. Comparative Study between Spiral computed Tomography and Ultrasound in Detecting Urolithiasis (Doctoral dissertation, Sudan University of Science and Technology).

10. Alnour MM. A Comparative Study between Spiral Computed Tomography and Ultrasound in Detecting Urolithiasis (Doctoral dissertation, Sudan University of Science and Technology).

11. Johnson EK, Faerber GJ, Roberts WW, Wolf Jr JS, Park JM, Bloom DA, Wan J. Are stone protocol computed tomography scans mandatory for children with suspected urinary calculi?. Urology. 2011 Sep 1;78(3):662-6.

12. Vijayakumar M, Ganpule A, Singh A, Sabnis R, Desai M. Review of techniques for ultrasonic determination of kidney stone size. Research and reports in urology. 2018;10:57.

13. Roberts MJ, Williams J, Khadra S, Nalavenkata S, Kam J, McCombie SP, Arianayagam M, Canagasingham B, Ferguson R, Khadra M, Varol C. A prospective, matched comparison of ultra-low and standard-dose computed tomography for assessment of renal colic. BJU international. 2020 Sep;126:27-32.

14. Roberson NP, Dillman JR, O’Hara SM, DeFoor WR, Reddy PP, Giordano RM, Trout AT. Comparison of ultrasound versus computed tomography for the detection of kidney stones in the pediatric population: a clinical effectiveness study. Pediatric radiology. 2018 Jul;48(7):962-72.

15. Ray AA, Ghiculete D, Pace KT, Honey RJ. Limitations to ultrasound in the detection and measurement of urinary tract calculi. Urology. 2010 Aug 1;76(2):295-300.

16. Verhagen MV, Watson TA, Hickson M, Smeulders N, Humphries PD. Acoustic shadowing in pediatric kidney stone ultrasound: a retrospective study with non-enhanced computed tomography as reference standard. Pediatric radiology. 2019 May;49(6):77783. 